\title{
Mapping Alternative Models of Global Politics
}

\author{
RafFaele Marchetti \\ Luiss University and John Cabot University
}

\begin{abstract}
This paper investigates the principal competing visions of global politics that are currently advanced in the public discourse about globalization in opposition to the traditional state-centered perspective. The first part of the paper develops an analysis of ideal models as cultural resources that grounds the different reading of human bonds. The second part applies the notion of ideal models to the new scenario of globalization, and identifies four alternative interpretations of the notion of global politics: namely Neo-liberalism, Cosmopolitanism, Alter-globalism, and Dialogue among Civilizations. The principal characteristics of these four notions are presented in order to map the current debate on the future of global politics.
\end{abstract}

One of the most heated debates on the political agenda, both national and international, concerns the social consequences and the political control of what is usually referred to as "globalization.", There can be no doubt that world ethical consciousness has been altered by the global transformations of the last decades. The social and political life of nearly every citizen has been dramatically affected by the blurring of national borders, which in the past have effectively limited relationships among individuals. In this process, characterized by the intensification of interaction and by the deepening enmeshment of local and global, economic concerns have undoubtedly taken the lead, but politics, law, and culture are also experiencing radical mutations that increasingly throw into doubt the legitimacy of traditional codes of conduct. From the assemblies of international institutions to national parliaments, from private sector meetings to civil society fora, the theme of the effects of the increased global interconnectedness on the life of citizens occupies the center of public discussion.

The focus of this debate on globalization is the inadequacy of the current institutional framework and its normative bases for a full development of the political sphere at the global level. Traditional political canons anchored in the nation-state and its domestic jurisdiction are increasingly perceived as insufficient, or indeed, self-defeating in a world in which socioeconomical interaction is, to a significant degree, interdependent. A contradictory double movement characterizes the relationship of contemporary international affairs to political legitimacy. While the conventional democratic assumption, according to which citizens have the right to self-determination through political participation, is

\footnotetext{
${ }^{1}$ Previous versions of this paper were presented at the 1st and 2nd Non-State Actors Workshops of the Garnet project-JERP 5.2.7 (Exeter and Sofia, 2006), the ISA annual convention (San Diego, 2006), and the SISP annual conference (Bologna, 2006). Many thanks for the discussion to all participants in those meetings. Special debt is owed to Irene Caratelli, Donatella della Porta, Mathias Koenig-Archibugi, Fritz Kratochwil, Anna Caffarena, Tony Lang, Lorenzo Mosca, Nathalie Tocci, and Peter Wagner for their insightful comments.
} 
increasingly recognized as the cardinal principle of politics both in international covenants and national constitutions, international affairs themselves create a situation in which such an entitlement is conversely limited and decreasingly guaranteed. Unstable financial markets, environmental crises, and unregulated migratory flows offer just few examples of phenomena that simultaneously and all too clearly remind us of the heavy interdependence of contemporary international system and of its political deprivation. These intense processes of global transformation functionally require increased transnational cooperation, and yet pose a continuous challenge to the effectiveness and legitimacy of "traditional" political life.

Acknowledging the limits of this political tension, alternative projects of global politics have been developed and mooted publicly in recent decades. Their common denominator consists in the attempt to go beyond the centrality of the sovereign state towards forms of political participation that allow for new subjects to "get into transnational politics" from which they have been excluded so far. These new would-be- or quasi-global political actors are part of the broad category of nonstate actors, which includes: international nongovernmental organizations (NGOs), transnational corporations (TNCs), networks and campaigns of civil society organizations and faith-based groups, transnational social movements (TSMs), transnational criminal networks, transnational political parties, regional public institutions, ${ }^{2}$ international private bodies, and individuals. Despite minor institutional experiments, most of these actors share the characteristics of effectively being excluded from international decision making mechanisms, ${ }^{3}$ and yet being more and more active on the global stage. International exclusion occurs in fact when political agents are deprived of their direct institutional entitlements to influence public decisions at the international and global level. At the moment, this is nowhere more visible than on the edge between national and international jurisdictions concerning political participation. Increasingly, decisions taken in one country affect people in other countries who do not have the possibility to express their consent because of their subaltern status as nonfellow, ergo disenfranchised, citizens. A state-based political system remains an unsatisfactory framework for self-determination of trans-border interests, such as those embodied by non-national or transnational political agents like migrants, people of trans-border religions, minorities, workers, etc. (Scholte 2004:22; Marchetti 2005). Both in cases where decisions taken in a given country have border-crossing consequences, and in those where decisions taken at the international level have effects disseminating internationally, most often the nonstate consequencebearer does not have significant power to register his or her "trans-border consent" or, indeed, dissent. International exclusion constitutes the critical target of most of the alternative projects of global politics that occupy the center of the public debate on globalization.

This paper investigates the principal competing visions of global politics that are currently advanced in the public discourse about globalization. These are models that prioritize different nonstate actors and suggest alternative modes of transnational political inclusion. The first part of the paper develops an analysis of ideal models as cultural resources that grounds the different reading of human bonds. The second part applies the notion of ideal models to the new scenario of globalization, and identifies four alternative interpretations of the notion of global politics: namely Neo-liberalism, Cosmopolitanism,

\footnotetext{
${ }^{2}$ Throughout this paper, public institutions and especially intergovernmental organizations are interpreted á la institutionalist, that is, they are taken to be primarily expression of the institution itself rather than, realist-like, of the single member states.

${ }^{3}$ This point does not, obviously, apply to the case of illegal criminal groups and terrorist networks that do not seek institutional inclusion, and to the case of international organizations.
} 
Alter-globalism, and Dialog among Civilizations. The principal characteristics of these four notions are presented in order to map the current debate on the future of global politics.

\section{Ideal Models as Cultural Resources}

Underpinning the debate on the political deficit in the global system are a number of ideological readings of globalization and global political phenomena that can be considered to be species of archetypes or ideal models of global politics. These ideal models can be considered as "meta-tanks," or cultural resources from which political actors draw their ideas and principles in order to formulate their political reference for action (Snow and Benford 2000:58). In being normatively substantiated, they form part of shared understandings that shape actors' identity and interests (Wendt 1995). "Ideal-types are heuristic devices which order a field of enquiry and identify the primary areas of consensus as well as contention. They assist in clarifying the primary lines of argument and, thus, in establishing the fundamental points of disagreement. They provide an accessible way into the mêlée of voices-rooted in the globalization literature but by definition corresponding to no single work [or] author" (Held and McGrew 2000:2). In order to illustrate better the notion of ideal model, a parallel can be drawn between ideal political models and ideologies (Laclau 1996; Gerring 1997). While both constitute fairly pervasive, integrated, and long-standing sets of beliefs and values, ideologies have a more wide ranging scope, in contrast to the politically limited scope of ideal models, as intended here. Ideologies can be conceptualized as interpretations of modernity in its entirety. More modestly, ideal models concentrate on normative politics, on its principled and institutional dimensions.

Political actors actively deploy ideal political models and ideologies to construct their contentious political references, in what has been named the interactive "politics of signification" or "collective action framing." Three elements can be distinguished in this process of political referencing: ideal models (composed by the condensation and coherentization of different elements of the frames), frames (cognitive social processes producing a determined reading of political reality), and political project (specific program for changing or preserving the political reality as interpreted according to the frame) (Goffman 1974; Laraña, Johnston, and Gusfield 1994; McAdam, McCarthy, and Zald 1996; Fisher 1997; Benford and Snow 2000; Andretta 2005). What distinguishes ideal models from political projects is their detachment from any specific political actor or action (content-orientation rather than action-orientation) (Oliver and Johnston 2000; Snow and Benford 2000). In opposition to the hybrid characteristics of political projects, an ideal model remains "uncontaminated," more static, and clearly distinguishable from other ideal models. Nonetheless, ideal models are not created in the abstract by "intellectuals in a vacuum." They are actually influenced in turn by social reflection, thereby including frames and political projects. Equally, while being rooted in ideologies and ideal models, frames are neither determined nor isomorphic with any single ideal model and they also are in continuous reciprocal relation with the social construction of politics. In the ultimate analysis, however, it is the single actor who creates his own political project by selecting and accentuating elements belonging to distinct ideal models and frames.

The formulation of the concrete political projects advanced by political actors passes through a complex process in which long-standing ideologies and ideal political models, mid-term political visions and circumstances, and contingent factors are combined and filtered through master frames and specific group frames, and rendered politically active (see Figure 1). Accordingly, it must be 


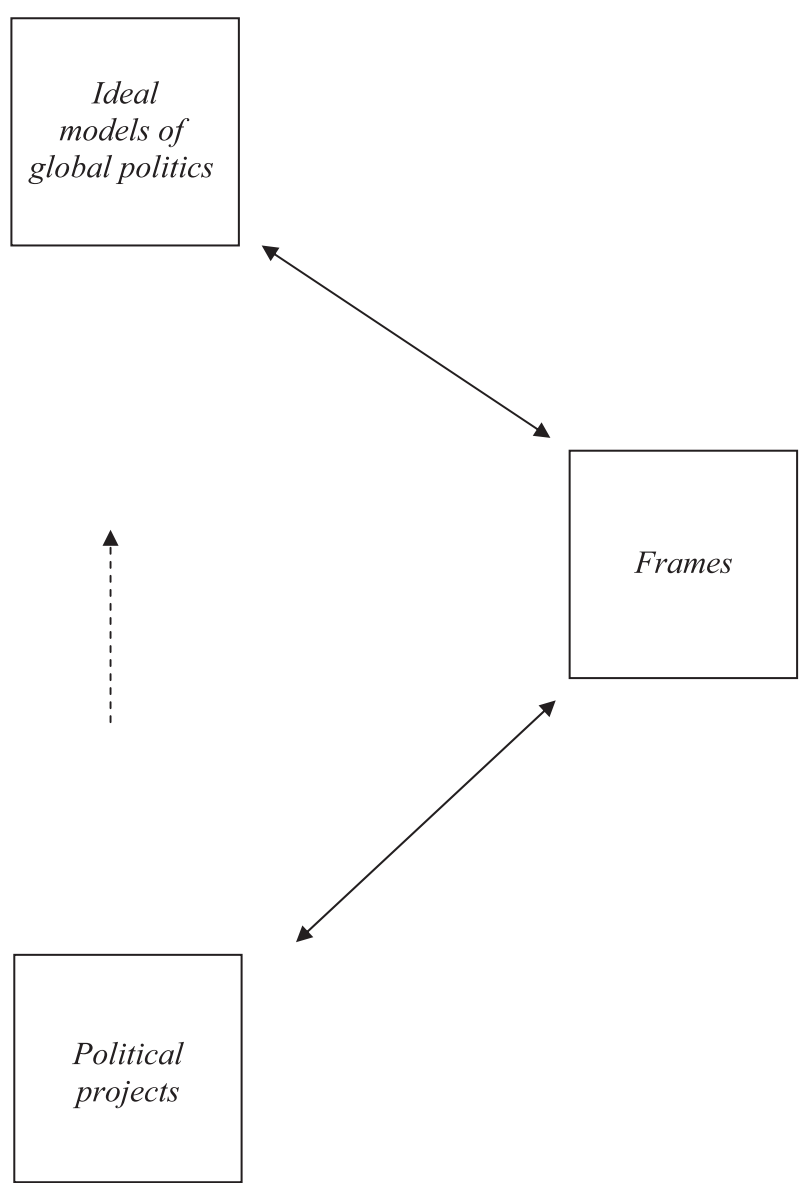

FIG. 1. Dynamics ideal models/frames/political projects.

noted that an actor can hold more than one model for different reasons. A political actor, for instance, is often a collective body (either an institution or a forum), and so it is intrinsically plural and changing in time. Seen from a highly normative point of view, the "pick and choose" underpinning the construction of a political projects by social actors produces a result that remains difficult to foresee and sometimes inconsistent. And yet, once a project is defined and adopted by political actors, it has a great impact in the shaping of global public discourse on global politics/justice, for it is key in motivating actors toward political mobilization.

The academic discourse on ideal models of global politics is very underdeveloped. Few attempts have been made to map ideological background visions of global politics, and they either lack a number of important components or remain too shallow to grasp the most significant characteristics of each specific model. Moreover, the task of mapping global political vision is also so far deficient to the extent to which it fails to connect visions to political actors and interests on the one hand, and visions to political actions on the other. Roughly speaking, the links among ideas, actors, and actions are still fuzzy at the global level, requiring further investigation. In order to succeed, this kind of research has to be interdisciplinary, for it requires the combination of a number of fields that are seldom integrated, including international political theory, international 
relations (especially the debate on norms), transnational political sociology, globalization studies, and international political economy. In this article, I will primarily concentrate on the model of global politics rather than on actors and actions. A relationship can (and will) be identified between any specific model and a set of actors and actions. However, as mentioned earlier, any actors shapes its own political project picking and choosing different components from different models, and this choice itself varies over time, so much so that the kind of association between models and actors later suggested can only be considered contingent.

\section{Global Politics and Its Ideal Models}

Patterns of globalization have accentuated the diminishing exclusivity of states as actors in international affairs (Czempiel and Rosenau 1992; Held, McGrew, Goldblatt, and Perraton 1999; UNDP 1999; Held and McGrew 2002b). Following an almost conventional definition, I interpret global transformations as a "process (or set of processes) which embodies a transformation in the spatial organization of social relations and transactions-assessed in terms of their extensity, intensity, velocity and impact-generating transcontinental or inter-regional flows and networks of activity" (Held et al. 1999:16). Globalization links distant communities and de-territorializes power relations, whilst simultaneously extending their reach beyond traditional domestic borders. While diminishing the exclusivity of states as international actors, this globalizing process has opened up spaces for new social actors (Keohane and Nye 1972; Higgott, Underhill, and Bieler 2000; Haufler 2001; Price 2003). Among nonstate actors, three categories can be identified: (1) public-interest-oriented nongovernmental actors, (2) profit-oriented corporate actors, and (3) public inter-governmental organizations. Nowadays, these nonstate actors play a significant part in international affairs, for they provide expertise and information (for example, technical help provided by NGO in development program), but also by dint of the fact that they influence political discourse, agenda setting, and law-making (for example, lobbying activities of advocacy or TNCs networks) as well as their part to play in the implementation of decisions (for example, service provider organizations in humanitarian actions) (Arts, Noortmann, and Reinalda 2001). And yet, nonstate actors are for the most part still formally excluded from institutional power.

A typical phenomenon of any democratization process occurring at the international level is precisely the sense of instability generated by the emergence of un-institutionalized actors and new legitimacy claims (previously unheard) in the public domain. These actors try to upgrade their missing political and institutional power in order to align it to their existing social and economic power. Those excluded actors claim inclusion into the political system through deploying different strategies from mild lobbying to harsh protest. Within this context of new political agency, an unprecedented global public domain consolidates in which old, state-centered visions of international affairs mix with new nonstatecentered visions of global politics, producing a complex map of ideological positions. This has been possible through the partial replacement of the Westphalian international system, in which authority and legitimacy was circumscribed, to reciprocally excluding territorial jurisdictions interacting exclusively at the intergovernmental level (Ruggie 2004). The global public domain remains a central place where new dimensions and new applications of global legitimacy are developed and advanced in contrast to current interpretations. This does not necessarily entail reformist or indeed revolutionary reading of legitimate global politics that influence concrete political action, but the mere chance of starting a dynamic of norms change in international politics makes this global public arena and its ideal content extremely important for current global politics 
(Finnemore and Sikkink 1998; Clark 2007). It is to this global public discourse and to its components that we need to look in order to understand the future, long-term transformation of global politics.

In this under-explored arena of discussion and contestation over the legitimate global social purposes, a number of distinct political positions can be identified. Few scholars have attempted such classification. These attempts are reported here in a scale that encompasses, broadly speaking, both anti-globalization and pro-globalization positions. ${ }^{4}$ Bond identifies five principal positions: specifically, global justice movements, third world nationalism, post-Washington consensus, Washington consensus, and resurgent rightwing (Bond 2004:20-21, 2007). Held and McGrew (2002a:99) acknowledge six positions: radicalism, statism/protectionism, global transformation, institutional reformer, liberal internationalism, and neo-liberalism. Pianta and Silva (2003:235-238) distinguish three projects that go by the names of neo-liberal globalization, globalization of rights and responsibilities, and globalization from below. Aguiton (2001) discerns three groups, called radical internationalist (beyond state and capitalism), nationalist (south), and neo-reformist (global governance). These categorizations provide a useful first orientation in the debate, nonetheless they are not fully satisfying for at least three reasons: (1) they provide only a limited range of alternatives (that is, Held \& McGrew; Pianta; Aguiton), (2) they fails to clearly distinguish between conventional (that is, state-based) and the new nonconventional models (that is, Bond; Held \& McGrew; Aguiton), and more important (3) they fail to provide a valid method to interpret politically these categories in the context of globalization.

Building on the previous discussion, the taxonomy here presented offers a new interpretation of the visions of global politics that avoids the deficiencies of the previous categorizations. First, the present proposal offers a wider spectrum of models of global politics in that includes the oft-excluded model based on civilizations. Second, it is based on the recognition of the novelty of those models that in disputing the centrality of the state in international affairs fully recognize the role of new political actors such as nongovernmental actors and individuals. Accordingly the taxonomy focuses only on nonconventional models, excluding models still anchored in the Westphalian paradigm, such as nationalism, liberal multilateralism, neo-imperialism, anarchical realism, etc. Third and more important, the taxonomy is constructed combining two key parameters of global politics: formation of political power (bottom-up and top-down) and attitude towards globalization (positive and negative). Looking at how political power engages on the one hand with the issue of institutionalization (formation of political power), and on the other with the issue of the globalization impact on the nexus politics-society-economics (attitude towards globalization) suggests us most clearly the contrasting political essence of the different models of global politics here under examination. These are the two key variables used to categorize the models of global politics, as in Table 1. More specific differences among the models are provided later in each specific section and summarized in Table 2 which comparatively draws the remaining key political features of each model.

Accordingly, four key interpretations of the notion of world polity can be identified as delimiting the range of nonconventional ideal alternatives available to the global political debate: (1) the vision of world capitalism as associated to a global free market and private economic actors, (2) the project for the democratization of international institutions as formulated in the cosmopolitan model with

\footnotetext{
${ }^{4}$ Despite sharing a number of points of convergence, this exercise should not be confused with other research agendas such as the institutional taxonomy of global governance arrangements (Koenig-Archibugi 2002), the epistemological categorization of theories and researches on globalization (Sklair 1999), the IR-style classification of world orders (Thibault 2003; Kacowicz 2005), or the social theory discourse on world-making of modernity (Goodman 1978; Nancy 2002; Karagiannis and Wagner 2007).
} 
Table 1. Principal variables in mapping models of global politics

\begin{tabular}{llll}
\hline & & \multicolumn{2}{l}{ Formation of Political Power } \\
\cline { 3 - 4 } & & Bottom-up & Top-down \\
\hline \multirow{2}{*}{ Attitude towards Globalization } & Positive & Cosmopolitanism & Neo-Liberalism \\
& Negative & Alter-Globalism & Dialog among Civilizations \\
\hline
\end{tabular}

reference to individuals and supranational institutions, (3) the radical vision hold by vast part of the social movements in terms of alter-globalism associated to civil society groups, and finally (4) the discourse on the dialog among civilizations which refers to macro-regional actors often defined in religious terms.

A number of clarifications need to be made in order to illustrate the table. Attitude towards globalization expresses the perspective that is entailed by each model. The model of alter-globalism is firmly against globalization for its detrimental effects on social life. Though it prescribes a different form of transnational organization, its rejection of the current form of globalization is clear. Similarly, the model of dialog among civilizations is also against current form of globalization for its negative and homogenizing impact on cultures and civilizations. In opposition to this, cosmopolitanism has a more positive attitude toward globalization in that global transformations are seen as epochal changes that can generate new and fairer political arrangements. Finally, the model of neo-liberalism is definitely the ideological paradigm underpinning the recent globalization of economic exchanges. Their attitudes towards globalization offer a clear first reference for ordering the four models that are suggested. A complete categorization cannot, however, be provided without taking into consideration a second crucial parameter.

The vision of political power formation offers the second key parameter for the present proposal. A formation of political power refers to the modes in which political power becomes institutionalized, to the crucial modes of interpreting and doing politics. Two alternative interpretations of this process are here taken into consideration. On the one hand, a bottom-up interpretation, according to which political power is diffused and disaggregated at the bottom of society. From these numerous and fluid centers of potential power, nonpolitical resources can be canalized into institutions in order to produce a political impact. This is the case for the model of alter-globalism, with its reference to grassroots groups or to the model of cosmopolitanism with its ultimate reference to individuals. On the other, a top-down interpretation, according to which political power is intense and concentrated at the top of society. From these few centers of actual power, nonpolitical resources can be canalized into institutions in order to produce a political impact. In agreement with such vision are the models of both dialog among civilizations, with its recognition of few cultural actors representing the whole civilizations, and neo-liberalism, with its acknowledgment of the primacy of the powerful global economic actors, especially TNCs.

A further consideration concerning human bonds needs to be presented before moving into the details of each ideal model. According to social theory, human actions can be interpreted with reference to four general bonds among individuals: social, political, economic, and cultural-religious (Wagner 2006; Karagiannis and Wagner 2007:Pt. II). While we assume that each frame of action includes elements belonging to several bonds, it is possible to identify the prioritized bond in each of them. Any action part of a larger frame can be interpreted as making primary reference of sense to a specific bond, while at the same time also secondarily referring to other bonds. The four models here presented offer a reading of global politics that at times valorize one or the other of the four 
TABLE 2. Main characteristics of nonstate-based models of global politics

\begin{tabular}{|c|c|c|c|c|}
\hline & Neo-Liberalism & Cosmopolitanism & Alter-Globalism & $\begin{array}{l}\text { Dialog among } \\
\text { Civilizations }\end{array}$ \\
\hline $\begin{array}{l}\text { Formation of } \\
\text { political power }\end{array}$ & $\begin{array}{l}\text { Top-down by } \\
\text { economic actors }\end{array}$ & $\begin{array}{l}\text { Bottom up by } \\
\text { individuals }\end{array}$ & $\begin{array}{l}\text { Bottom up by } \\
\text { civic groups }\end{array}$ & $\begin{array}{l}\text { Top down by } \\
\text { cultural élites }\end{array}$ \\
\hline $\begin{array}{l}\text { Attitude toward } \\
\text { globalization }\end{array}$ & Supportive & Reformist & Radical alternative & Conservative \\
\hline $\begin{array}{l}\text { Human bond } \\
\text { Agency }\end{array}$ & $\begin{array}{l}\text { Economic } \\
\text { Individual/ } \\
\text { collective } \\
\text { (firms and } \\
\text { consumers) }\end{array}$ & $\begin{array}{l}\text { Political } \\
\text { Individual } \\
\text { (citizens) }\end{array}$ & $\begin{array}{l}\text { Social } \\
\text { Collective } \\
\text { (grassroots groups) }\end{array}$ & $\begin{array}{l}\text { Cultural-Religious } \\
\text { Collective } \\
\text { (civilizations and } \\
\text { cultural élites) }\end{array}$ \\
\hline Pluralism & $\begin{array}{l}\text { Universalism } \\
\text { Homogeneity }\end{array}$ & $\begin{array}{l}\text { Universalism } \\
\text { Homogeneity }\end{array}$ & $\begin{array}{l}\text { Pluralism } \\
\text { Heterogeneity }\end{array}$ & $\begin{array}{l}\text { Pluralism } \\
\text { Heterogeneity }\end{array}$ \\
\hline $\begin{array}{l}\text { Political } \\
\text { principles }\end{array}$ & $\begin{array}{l}\text { Freedom } \\
\text { Competition } \\
\text { Globalism }\end{array}$ & $\begin{array}{l}\text { Globalism } \\
\text { Universalism } \\
\text { Participation } \\
\text { Procedural } \\
\text { fairness }\end{array}$ & $\begin{array}{l}\text { Place-basedness } \\
\text { Participation } \\
\text { Autonomy } \\
\text { Diversity } \\
\text { Solidarity }\end{array}$ & $\begin{array}{l}\text { Diversity } \\
\text { Respect } \\
\text { Goodwill } \\
\text { Nonviolence }\end{array}$ \\
\hline $\begin{array}{l}\text { Institutional } \\
\text { project }\end{array}$ & Self-regulation & $\begin{array}{l}\text { Federation of } \\
\text { individuals }\end{array}$ & Groups, networks & Macro-regionalism \\
\hline
\end{tabular}

traditional human bonds. In such a way, these models of global politics cover the entire spectrum of human interaction. Having clarified the principal parameters that allow for a demarcation of the four models, it is now time to move to the specific characteristics of each models of global politics.

\section{Neo-Liberalism}

The ideal model of neo-liberalism is centered on the primacy of the economic bond. While acknowledging the relevance of the other traditional human bonds, neo-liberalism recognizes predominance to the economic aspect of human life. The model makes primary reference to private economic actors (entrepreneurs, firms, business networks, and consumers) as key agents in the political system. Accordingly, political power is interpreted as being managed in a decentralized way by consumers, and especially entrepreneurs grouped in transnational élite networks. Powerful firms are seen as key players in a universal political system that is intended as homogeneous and minimal, as a sort of global invisible hand. Public institutions are seen as universal tools allowing for a fair political life, beyond the limitations of a state-based system. Within the political and economic context of globalization, neo-liberalism offers the clearest project in support of a libertarian globalization.

Neo-liberalism is an ideal model of global politics based on a number of distinct principles, including individual freedom, competition, and globalism. The value of freedom affirms the ultimate and non-negotiable value on personal autonomy intended as entrepreneurial capacity to individual success and economic development (Rand 1961; Nozick 1974; J.M Buchanan 1976). Competition draws a world in which free individuals are moved by the search for economic success, thus unintentionally pushed toward collective progress and technological innovation by the constant conflict over scarce resources (Becker 1976; Rothbard 1982). Finally, globalism recognizes the moral and political imperative of having a worldview that encompass the entire humanity towards forms of increasingly 
deeper integration within a single world system, beyond suboptimal state jurisdictions (Sassen 1996; Arrighi 1999; Ohmae 1999).

Neo-liberalism advocates a vision of global politics that is minimal and selfmanaged by individuals and economic firms. Individuals are free to act as they think it is best both as consumers (consumer sovereignty) and as entrepreneurs (capitalist freedom). Political institutions are thought to be necessary because of the imperfection of the market, and in any case they are intended minimally a la laissez-faire. Vast parts of what is now considered as competence of political institutions (both at the state and the intergovernmental level) should thus be left to the self-regulation of society or to the technical management of mono-functional organizations of global governance. Global business community (Van der Pijl 1998; Carroll and Carson 2003) and global civil society (as composed by individuals rather than groups) would self-organize international affairs for the best (Sally 2001; Wolf 2004). A full development of a deregulated globalization is pursued in which there is complete free trade of goods, free communication of information, and free movement of people. Such kind of globalization is seen as the most adequate environment for economic growth and for the spread of democracy beyond the limits of nationalistic policies (Bhagwati 1997; Norberg, Tanner, and Sanchez 2003; Bhagwati 2004).

Replacing the model of embedded liberalism-a combination of free trade and national political systems (Ruggie 1983) - the model of neo-liberalism gathered momentum as a rapidly growing alternative in the late seventies, and became hegemonic in the eighties and nineties of the twentieth century, under the label of the Washington Consensus (Harvey 2007). Within the rising tide of globalization, two main trends marked the new paradigm: a strong accent on privatization (as opposed to welfarism) and on flexibility (as opposed to Taylorism). Market fundamentalism, liberalization, deregulation, and budget austerity were also prominent. The teaching of classical (such as Bastiat [1845] 1964) and contemporary economists (such as Bhagwati 2004), and the political instructions of Margaret Thatcher (Brittan 1988) and Roland Reagan (Gill 1990) provided a significant practical and theoretical underpinning for this paradigm change (Ruggie 1995; Bello 2002:§I; Vercelli 2003). This new model of international affairs was soon adopted, though always in degrees, by major international institutions, including the World Bank, the International Monetary Fund, and the General Agreement on Tariffs and Trade rounds/World Trade Organisations (Woods 2000; Stiglitz 2002). Finally, the creation of the World Economic Forum in Davos served as a nonconventional reference point for this libertarian tendency that is still intensely characterizing current international political-economic arrangements (Schwab et al. 1999; Graz 2003; Fougner 2005; Porter, Schwab, and Lopez-Claros 2005).

The implementation of neo-liberalism has been tightly connected with the diffusion of global governance mechanisms (Keohane 1984; Czempiel and Rosenau 1992; Rosenau 1997; Held and McGrew 2002b). Global transformations have provoked a rising need for wider and deeper international cooperation, which has eventually led to the establishment of new mono-functional institutions and networks (Slaughter 2004; Zürn 2004). As a consequence, the international system is arguably changing into polyarchy, a system composed of diverse authorities, often on unequal formal standing, such as states, subnational groups, and transnational special interests and communities, including both private and public bodies (Rosenau 1992:284-285). A continuously growing net of political norms and legal rule-making with a low degree of democracy have increasingly characterized the institutional side of contemporary international society, eroding the legitimacy of both the state and classic international law. The mushrooming of intergovernmental (for example, the G7/8 meetings) and (semi) private agencies (for example, the Internet Corporation for Assigned Names and Numbers or the 
Society for Worldwide Interbank Financial Telecommunication) have put under pressure, if not supplanted, the traditional UN-centered international system, creating alternative mechanisms of global governance. Within this innovative institutional framework, TNCs are often interpreted as catalysts to a borderless world, acting at times unintentionally as functional actors for global integration (Barnet and Müller 1974; Barnet and Cavanagh 1994; Korten 1995). The model of neo-liberalism as in relation to the expansion of globalization has doubtlessly been the most discussed in the recent decades. This brief presentation will thus suffice here and will allow more space for the three remaining models which have received comparatively less attention in the public discussion.

\section{Cosmopolitanism}

The ideal model of cosmopolitanism is centered on the primacy of the political bond. While acknowledging the relevance of the other traditional bonds between human beings, cosmopolitanism recognizes predominance of the political and civic aspect of human life. The model makes primary reference to individuals as key actors in the political system. Accordingly, political power is interpreted as originated by citizens and managed in a global, multilayered way. Public institutions are foreseen as universal tools to allow for a fair political life, beyond the limitations of a state-based system. Within the political and economic context of globalization characterized by a high degree of political exclusion, cosmopolitanism offers a reformist project based on social-democratic and liberal values, that aims to democratize the system of globalization without altering its fundamentals.

Cosmopolitanism is as old as classic Greek philosophy (Heater 1996), but gained new recognition in the last three decades. Its emergence began in the late seventies, with the debate on transnational justice and the Vietnam War. From that event, the public discussion on international ethics grew considerably (Singer 1972; Pogge 2002), up to the point of becoming an established perspective in international studies (Archibugi, Held, and Köhler 1998). Three dimensions or phases of contemporary cosmopolitan thinking can be identified: the original ethical phase which originated in the $1970 \mathrm{~s}$, the institutional moment which consolidated in the 1990s, and finally the social segment from 2000 on (Marchetti 2008a:Pt. II).

Cosmopolitanism is a theory of justice according to which the scope (not only the form) of justice is taken to be universal, as no discrimination is justified when considering the ultimate entitlement of every citizen to control his or her destiny (Caney 2004). Individuals are entitled to rights (and assigned duties) that have an ultimately universalistic nature, that is, they are transcultural and valid in any political and social context, because individuals are considered to be ultimately world citizens. Humanity is thus considered as a single ethical community-cosmopolis (cosmos: universe; polis: city), or as belonging to a single polity. Against group-based theories such as communitarianism and nationalism, which typically recognize the political priority (at times even absolute) of a discrete community, cosmopolitanism holds that a proper account of the moralpolitical personality cannot but be universalistic and all-inclusive, and that all individuals thus have an equal entitlement to political recognition. This means that the coexistence of global and national/local principles of political justice is possible, provided a global top-down ordering is established, that is, national jurisdictions are drawn by an overarching authority and national boundaries remain secondary when issues of global justice arise (Marchetti 2008b).

Cosmopolitanism is an ideal model of global politics based on a number of distinct principles including globalism, universalism, participation, and procedural fairness. Globalism affirms the necessity of having an all-inclusive view that 
encompasses the entire humanity (Barry [1991] 2005). Universalism states that fundamental characteristics of human being do not vary according to country of birth, thus universal values apply to each individual worldwide (Caney 2004) Participation maintains that individuals have a political right to take part in public life in all spheres that affect them, they are thus entitled to transnational citizenship (Kuper 2004; Marchetti 2006). Procedural fairness holds that the political life has to be shaped according to a formal rather than substantial principle of justice (Pogge 1992; Van den Anker 2006).

According to the model of cosmopolitanism, politics focuses on the macrolevel, for it aims to correct current system of international exclusion through an institutional reform from above. Contemporary institutional arrangements are to be criticized for their incapacity to guarantee democratic congruence between decision makers and decision takers. Consequently, political contestation of most institutions has to be carried out with the intent of revising their internal structure and opening up new channels of representation (Held 1995). Strengthened multilateralism in the short term and federalism in the long term constitute the most promising institutional options for a world in which individuals would retain their status of democratic and free choice-makers (Gould 2004; Marchetti 2008a; Archibugi 2008).

The influence of cosmopolitanism is nowadays increasing expanding beyond the limited academic circles into the realm of global politics. Primary references in this regard are a number of components of the United Nations system. A typical application of the theory of cosmopolitanism can arguably be found in the United Nations Convention Relating to the Status of Refugees (1951), according to which asylum is granted to fleeing individuals as citizens of the world (Hassner 1998). Despite drawing a cosmopolitan status only by contrast, the Convention nevertheless identifies the refugee as a person with universal claims of assistance, that is, with cosmopolitan status (art. 1). Beyond the specific Refugee Convention, other components of the United Nations system have been interpreted cosmopolitically (Bienen, Rittberger, and Wagner 1998; Taylor 1999; Archibugi, Balduini, and Donati 2000; Cronin 2002; Day 2002; Hayden 2005; Norris 2008). In particular, reference is also usually made to the environmental domain with the Commission on Global Governance (1995) and the United Nations Framework Convention on Climate Change, more specifically the Kyoto Protocol. Another significant reference is the International Criminal Court (ICC) with its "quasi-universal jurisdiction," as well as to the new paradigm of the Responsibility to Protect which would support the case for humanitarian intervention regardless of state sovereign prerogatives (ICISS 2001; Archibugi 2004; United Nations 2004, 2005; Arbour 2008). As recently restated by the UN High Commissioner for Human Right, Louise Arbour: "Rooted in human rights and international humanitarian law, the norm [of the Responsibility to Protect] squarely embraces the victims' point of view and interests, rather than questionable State-centered motivations. It does so by configuring a permanent duty to protect individuals against abusive behaviour [...]. At its core, the norm asserts a broad international public interest predicated on universal human rights" (Arbour 2008:448).

Among other international organizations adopting a number of cosmopolitan tenets are the United Nations Educational, Scientific and Cultural Organization (UNESCO) and the World Trade Organization (WTO). UNESCO has been holding for a long time the vision of global humanism that overlaps in several aspects with cosmopolitanism. Scientific humanism-the main philosophical framework contributing to the creation of UNESCO-has influenced both UNESCOs selfunderstanding and its activities such as "The Universal Ethics Project" (UNESCO 1998; Kim 1999). Scientific humanism is a philosophical vision that couples the advance of scientific knowledge with the diffusion of a common 
philosophical framework. Key into this is the promotion of a universal system of education to peace, which would foster the emergence of a global community based on science, humanism, and human rights (Asher 1950; UNESCO 1994; Pavone 2007). The WTO, especially under the leadership of its current director general Pascal Lamy, is striving to moderate its predominantly neo-liberal outlook with a cosmopolitan sensitivity. Discussion is undergoing on how to enhance transparency on the one hand, and consultation and cooperation with NGOs on the other. Civil society intermediation is in fact considered increasingly crucial for the social legitimacy of WTO policies (Lamy 2001; Petersmann 2001a,b; Buchanan 2003; Charnovitz 2004).

The European Union is also often associated to the ideal model of cosmopolitanism. The European Parliament is at times considered as the most advanced prototype of a transnational form of political representation in parallel to governmental representation (Pogge 1997, 2004; Cabrera 2005). Similarly, the (would-be/former) "European Constitution" of the European Union and the European Court of Human Rights of the Council of Europe are considered forms of cosmopolitanism thanks to their universal jurisdictions, though with a regional scope (Bellamy and Castiglione 1998; Eleftheriadis 2001, 2003; Delanty 2005; Eriksen and Fossum 2005; Eriksen 2006). Moreover, the foreign policy of the European Union is interpreted normatively in a way that overlaps with a number of cosmopolitan tenets. Beginning from Duchêne's argument on Europe as a civilian power in 1970s (Duchêne 1972), passing through the vision of Europe as normative power (Manners 2002, 2006), and reaching the most recent paradigm of Europe as an ethical power (Aggestam 2008), the EU foreign policy has frequently been associated to a universalistic/cosmopolitan paradigm based on human rights, democracy, and rule of law (Sjursen 2006:249). A recent variant of this consists in the interpretation of the European Union as a cosmopolitan empire (Beck and Grande 2004, Trans. 2007).

\section{Alter-Globalism}

The ideal model of alter-globalism is centered on the primacy of the social bond. While acknowledging the relevance of the other traditional bonds between human beings (that is, political, economic, and cultural), alter-globalism recognizes predominance of the social aspect of human life. The model makes reference to grassroots organizations (for example, civil society organizations, social movements, transnational social networks) as key actors in the political system. Accordingly, political power is interpreted as being managed through a rich network of local groups that preserves pluralism and heterogeneity. Within the political and economic context of globalization, characterized by a high degree of political and economic exclusion, alter-globalism offers the clearest radical alternative to the current global transformations.

Beyond opposing neo-liberal globalization, it is highly significant that alter-globalism also emerged from an antagonism towards previous cosmopolitan theory. From this perspective, cosmopolitanism would allegedly be too close to neo-liberal capitalism, would rely on too minimal a set of abstract prescriptions that are far from popular experience, would fail to connect norms to practices, and would accordingly fails to champion the claims of local groups, remaining too attached to élites. In response to this critical focus, alter-globalism presents itself as subaltern, thick, embedded, and rooted. It claims to be subaltern because it focuses on those voices that come from minorities, often from the south of the world, and not from the western centers of global governance. It is thick because it is imbued with solidaristic principles of social justice, and is not minimalist in terms of liberal nonharm. It is embedded because it is inserted within a social context characterized by intense mutual obligations and feelings 
of attachment to a comprehensive political experience, rather than referring to loose institutional relationships. Finally, it is rooted in that it emerges from local practices and remains tightly connected with political struggles from below, in opposition to élitist management.

In contrast to the supposedly constitutive flâneurisme of cosmopolitanism, alter-globalism highlights the inevitability of relying on local factors for building up a viable political community. Social cohesion and solidaristic ties are needed for any political project. According to this perspective, any political struggle needs to be embedded within local factors, within local struggles, to be effective and able to mobilize people. Social and political bonds are key elements for generating local and particularistic mutual obligations, which in turn are the true bases for eventual political solidarity, be it local, national, or transnational. In sum, alter-globalism can be understood as a model structured around five paramount principles: place-basedness, participation, autonomy, diversity, and solidarity. Place-basedness maintains the importance of localism as an unavoidable and critical resource for social and political life (Dirlik and Prazniak 2001; Osterweil 2005; Gibson-Graham 2006). Participation as nonhierarchical and horizontal public engagement constitutes the second major element of the model of alter-globalism (Holloway 2000; Polletta 2002; Fung and Wright 2003; della Porta 2005). Autonomy is also crucial for distinguishing the model of alter-globalism, in that it asserts the legitimacy of communal authority (Lang and Hines 1993; Hines 2000; Rajagopal 2003; Starr and Adams 2003). Diversity envisages a plurality of cultural projects, a movement of movements, "a world in which many worlds fit," as the Zapatistas would say (de Sousa Santos 2005; Tarrow 2005). Solidarity, finally, stresses the importance of transnational collaboration in overcoming local political difficulties (Smith, Chatfield, and Pagnucco 1997; Brecher, Costello, and Smith 2000; Smith 2002).

According to the model of alter-globalism, politics thus focuses on the microlevel, for it aims to change society and economy in its own place through grassroots processes. In opposition to mainstream politics, proponents of this position argue that such a grassroots perspective remains the most effective strategy for impacting on the political system at large and thus society. The first step toward the implementation of the alter-globalist political project is fierce opposition to the actual institutional arrangements of global governance (Amin 1985; Tarrow 1998; Gills 2000; O’Brien, Goetz, Scholte, and Williams 2000; Bello 2002; Armstrong, Farrell, and Maiguashca 2003; Bond 2004). Social movements and civil society organizations are seen as key actors in a fight against power structures that can at times take the form of direct action beyond current legality (de Sousa Santos 2002). Despite some minor reformist views, the bulk of alter-globalist logic tends toward "abolishing rather than polishing" institutions such as the World Bank, the International Monetary Fund, and the WTO. These institutions are considered to be so embedded in a system of power organized from above that the possibility of reforming them properly and democratically is seen as minimal. Hence, and contrariwise, the political aim remains threefold: stopping the widening of institutions' competencies in the short term, reducing their scope in the mid-term, and closing them down in the long term.

The alter-globalism political perspective does not preclude, however, positively envisaging institutional structures, even at the international level (Falk 1995; Rikkila and Sehm-Patomäki 2001; Patomäki and Teivainen 2004; Falk 2005; Monbiot 2005). These are admitted and actually encouraged, provided they are constructed from below, such as in the case of transnational solidarity networks. The actual content of each political project to be developed from below is not predetermined, for it is left to the self-determination of each group, much as each individual is granted freedom of choice. Even in those cases in which there is an "import" from outside (for example, a downscale shift of a global project 
such as the many local Social Fora), this can only be justified provided it fits with and accommodates local political projects. From this point of view, alter-globalism offers a sort of politics without ideology, a caminar preguntando (Trans.: walk while questioning) as the Zapatistas would say. This diffuseness and global rootedness leads to a process increasingly involving more and more parts of the world (de Sousa Santos and Rodríguez-Garavito 2005; de Sousa Santos 2006). The exclusionary logic of neo-liberal globalization would thus be reversed by the struggle of TSMs against transnational exclusion.

Alter-globalism slowly emerged in the last decades of the twentieth century and more decisively at the turn of the millennium, through the intensification of cross-border mobilizations of TSMs and global civil society more in general (Tarrow 2005; Pianta and Marchetti 2007; Smith 2007). The first signals of this emergence can be traced back to the 1970 s in relation to the "new social movements" concentrated around the themes of peace, human rights, solidarity, development, ecology, and women's issues. In the following decade, these still scattered movements gained a more acute awareness of their political potential, together with capacity for a strengthened self-organization.

Major international events, especially the UN thematic conferences, provided opportunities for meetings, exchanges, and cross-border initiatives, creating a space for transnational civil society actions. In 1972, the UN Conference on the Human Environment held in Stockholm saw the participation of a few hundred NGOs (Conca 1995); in 1974, the World Food Conference in Rome included an active presence of NGOs (Van Rooy 1997). Large NGO forums were also held in 1975, when the First World Conference on Women held in Mexico City launched the UN Decade for Women, as well as in succeeding Conferences in 1980 in Copenhagen and in 1985 in Nairobi (Chen 1995). The 1992 Rio Conference on the Environment and Development saw the presence of 2,400 NGO representatives; the parallel NGO Forum saw 17,000 participants. In 1993, the UN conference on human rights in Vienna saw the participation of thousands of civil society activists and addressed a key issue long neglected by states in the Cold War (Smith, Pagnucco, and Lopez 1998). In 1994, the Cairo conference on population led 1,500 civil society groups from 113 countries to forge new links around concerns regarding the conditions of women, families, and societies in the North and South. In 1995, the Copenhagen World Summit on Social Development and the Beijing World Conference on Women led to a new visibility, relevance, and mobilization for global civil society. In 1998, civil society organizations played a major role at the conference establishing the ICC (Pianta and Silva 2003; Pianta and Zola 2007).

In the 1990s, global social movements succeeded in consolidating transnational networks and organizing separate campaigns. Particularly relevant among them are the campaign for the establishment of the ICC (1995) (Glasius 2005; Cakmak 2008), the Jubilee campaign on Third World debt (1996) (Pettifor 1998), the campaign against the Multilateral Agreement on Investment (1998) (Wood 2000), the International Campaign to Ban Landmines (1992) (Faulkner 2007), and the Treatment Action Campaign on HIV and AIDS (1998) (Seckinelgin 2007). Along the complex road of transforming cross-border activism on specific issues into global social movements centered on more global political challenges, a major development with a pervasive influence occurred with the Zapatista insurgency in Chiapas, Mexico, in January 1994. This insurgency, in fact, turned what could have been a typical, locally focused Latin American guerrilla action into a much broader challenge to the injustice of neo-liberal globalization (Schulz 1998; Morton 2002; Olesen 2005; Pianta and Marchetti 2007).

With the new millennium, a structural scale shift occurred in the nature, identities, repertoires of action, and strategies of global social movements. The turning point in all of these respects was the creation of the World Social Forum as a 
space for the meeting of all organizations, social movements, and individuals that have challenged neo-liberal globalization. In January-February 2001, the first World Social Forum was held in Porto Alegre, Brazil, followed every year by ever larger events. It moved in January 2004 to Mumbai, India, returned to Porto Alegre in January 2005, decentralized to three continents in 2006, and move to Nairobi, Kenya in 2007 and Belem, Brazil in 2008. Dozens of regional and national Social Fora have been held on all continents, with thousands of organizations from all continents attending each one; the total number involved in these initiatives may be on the order of a few million people (Seoane and Taddei 2001; Teivainen 2002; Sen, Anand, Escobar, and Waterman 2004; Smith 2004). Together with the establishment of the World Social Forum, the other most important novelty of recent years has been the organization of global days of action, with millions of participants in demonstrations and events in hundreds of cities all over the world. Such events took place against the US war and occupation of Iraq on February 15, 2003, March 20, 2004, March 19, 2005, and March 18, 2006. The first of these dates was identified by the New York Times as the birth date of global public opinion and civil society as a "second superpower" (Tyler 2003). A radical challenge to the project of neo-liberal globalization emerged as a powerful unifying symbol for the struggles of resistance and in the search for political, economic, and social alternatives (Smith et al. 1997; Anheier, Glasius, and Kaldor 2001; Smith and Johnston 2002; della Porta and Tarrow 2005; Pianta and Marchetti 2007).

\section{Dialog among Civilizations}

While the civilizational paradigm slowly emerged as a significant model of global politics only in the last few decades, it nonetheless constitutes a robust component in the discussion about globalization. The civilizational model is centered on the primacy of the cultural and religious bond. While acknowledging the relevance of other traditional human bonds, such as economic and political bonds, the discourse on civilizations recognizes the cultural and religious aspect of human life as predominant. The model makes primary reference to civilizations and cultural élites as key actors in the political system. Accordingly, political power is interpreted as being managed in a decentralized way by intellectual and religious leaders. Religions and macro-regional bodies are seen as key players in a political system that preserves pluralism and heterogeneity. Within the political and economic context of globalization, characterized by a high degree of political and economic exclusion, the perspective of civilizations offers grounds for a conservative rejection of current global transformations.

The model of the clash/encounter of civilizations is centered on the notion of civilization intended as the ultimate cultural reference, beyond any other local and national element. Civilization is thus the highest cultural grouping of people and the broadest level of cultural identity. While the notion of identity is reinterpreted as multilayered, civilizational identity is acknowledged as the ultimate, most encompassing layer. Civilizations are accordingly interpreted as doublenatured. While externally civilizations present themselves as monolithic, internally they allow for moderate pluralism. Civilizations are relatively stable social references, though they may overlap, include subcivilizations, and change over time. As a matter of fact, civilizations have arisen and fallen throughout history. What is interesting within the clash/encounter of civilizations approach is that with the recognition of the West's loss of centrality comes also the recognition of other non-western civilizations' full status as antagonists/dialogical companions.

According to the thesis of the clash of civilizations, the key mode of the relationship between civilizations is conflict and competition. While states remain important actors in global politics, conflicts will spring up between civilizations 
through the fault lines, that is, those states that are on the border or even divided between two civilizations (torn countries). Civilizations need not necessarily collide, but history proves that this is the most likely outcome. Remaining anchored to history, the thesis of the clash of civilizations claims to be purely descriptive. Accordingly, the reasons for conflict will thus be more related to cultural aspects than to ideological or economical factors. Key factors contributing to conflict principally relate to the fact of irreducible cultural differences. Civilizational divergences are basic and irreconcilable. Since they are less mutable they are also less prone to compromise. Globalization also contributes to civilizational tension for a number of reasons. On the one hand, globalization increases the awareness of the other; this allows for the rediscovery of one's own identity but also generates opportunities for conflict. On the other hand, economic modernization is blending long-term local identities, and as these fade, larger, civilizational, and world religion identities are supplying a functional substitute (Huntington 1996).

While sharing the ultimate assumptions on the nature of civilizations with the clash of civilizations model, the model of the encounter of civilizations is more inclined to conceive normatively the possibility of dialog among different cultures, and also the possibility of political cooperation. Within this perspective, there are four key principles. First, diversity maintains that cultural frameworks are irreducible to one another, and thus rejects universalism in the name of a reaffirmed pluralism (Dallmayr 1996; Petito 2007). Second, respect entails equal treatment among different civilizations and refuses the normative hierarchies used by the ninetieth-century discourse on civilizations versus barbarians (Manoochehri 2003). Third, goodwill is seen as the crucial component for starting up a dialog that leads to reciprocal understanding (based on the hermeneutic method) and a nearing of different civilizations (Dallmayr 2001). Finally, nonviolence prescribes peaceful ways of interacting (Tehranian and Chappell 2002).

According to the civilizational model in both its conflict and dialogical variants, politics focuses on the high institutional level of exchange among élites. In contrast to the homogenizing tendency of current global transformations, this position fosters a multipolar world, in which mutual coexistence allows for the competition, or alternatively for the flourishing, of different cultural and political traditions. A major ideological foe of the model of civilizations is so-called neo-liberal globalization, with its equalizing tendency that neglects cultural differences. Politically speaking, this means that multilateral projects aiming at developing regional cooperation within and among different civilizational areas have to be supported (Camilleri, Kamal, and Majid 2000; Camilleri 2004; Cassano and Zolo 2007). A possible reform of the UN Security Council with civilizational representation would offer a valid institutional framework for this model (Mundy 2006).

Incipient attempts to recognize the centrality of the notion of civilization in international affairs occurred in the late nineteenth century, with the establishment of the Parliament of the World's Religions (1893), and in the first half of the twentieth century, with the creation of the World Congress of Faiths (1936); but it was only in the 1970 s and 1980s that a clear recognition of the civilizational factor as a key component of international relations emerged. It was doubtless the publication of Huntington's famous article on the "Clash of Civilizations" in 1993 (Huntington 1993; Foreign Affairs 1996; Huntington 1996) that turned what had originally been a predominantly religious discussion into a fully fledged political debate. The events of $9 / 11$ only boosted the attention given to Huntington's thesis and initiated a campaign of division along civilizational lines that is profoundly marking today's global politics.

In reaction to Huntington's thesis, a number of political statements and theoretical formulations in terms of dialog among civilizations have been developed 
not only in academia, but also in public discourse and in institutional discussion. In academia, Dallmayr and others offered a robust foundation for the dialog of civilizations in hermeneutic terms (Dallmayr 2003). In the public political domain, the backing of the idea of a dialog of civilizations by the centennial meeting of the Parliament of the World's Religions (in 1993) (Küng and Kuschel 1995), and the World Public Forum-Dialog of Civilizations (World Public Forum 2004), offered a concrete space for interaction. A number of key emergent global players supported the idea, including former Russian President Vladimir Putin (together with the Patriarch of the Russian Orthodox Church) (Putin 2005, 2007), Chinese President $\mathrm{Hu}$ Jintao (2006, 2008), and especially former Iranian President Mohammad Khatami (1998, 2000, 2001, 2006). Beyond Iran, in the Islamic world, the idea of civilizations was also favorably received (ISESCO 2001, 2004). The European Commission (2004) with its President Prodi established an High-Level Advisory Group for the Euro-Mediterranean Dialog. And above all, the UNs institutional backing-with the designation of 2001 as the year of the Dialog of Civilization (Picco 2001; United Nations 2001a,b), and with the initiative on the Alliance of Civilizations (2004) cosponsored by the Spanish Prime Minister Jose Luis Rodriguez Zapatero and his Turkish equivalent Recep Tayyip Erdogan which generated a United Nations High-Level Group on this topic (United Nations 2006; Manonelles 2007) —was key in the consolidation of this discourse. Today, civilization is firmly established as a key concept for an interpretation of global politics beyond a limited state-based perspective.

\section{Conclusions}

In this paper, the major nonconventional models of global politics have been presented. They constitute the ideal background of the current political project advanced by nonstate actors in the global arena. While translating to the global domain a number of characteristics of domestic politics, these models also present an innovative conceptualization of the political discourse. Going beyond traditional state politics as anchored in parties and national representations, these model envisage a new system from which new actors and new social claims can emerge. Ideal models of global politics denounce the current exclusionary system of international affairs, in contrast stressing the need for its reconstruction on different, democratic bases. What is claimed is a political voice, that is, enfranchisement in global affairs from which they are excluded. From the religious perspective to participatory democracy, from transnational citizenship to global market, new understandings of the polity, that challenge traditional intergovernmental politics, emerge within the framework of globalization.

The future of global politics will perhaps emerge from here. Traditional statecentered approaches to international relations will inevitably have to engage with these new forms of political agency in the age of globalization. The end result cannot be foreseen. But it is reasonable to expect the partial inclusion of a number of tenets of these alternative models in the overall international institutional framework. If we take into consideration their increasing social and economic power, the voice that this kind of actors claims in global politics cannot be denied indefinitely without exposing the system to a certain degree of instability. The most likely result, signs of which are already evident in some instances of global governance, will be a combination of traditional intergovernmental mechanisms with new forms of governance structures in which these nonstate actors will have an increasing significance and political power. From here the issue of rethinking legitimacy at the global level from a non-exclusively western-state-centric point of view will be unavoidable. Future research agendas will accordingly include both the positive investigation of how the new alternative tenets of the models presented here will be received and perhaps incorporated into 
mainstream global politics, and the normative investigation on the legitimacy of the future global institutional arrangements in view of the new actors present on the global stage.

\section{References}

Aggestam, Lisbeth. (2008) Introduction: Ethical Power Europe? International Affairs 84(1):1-11.

Aguiton, Christophe. (2001) Le Monde Nous Appartient. Paris: Plon.

Amin, SAmir. (1985) Delinking: Toward a Polycentric World. London: Zed.

Andretta, Massimiliano. (2005) Il Framing del Movimento Contro la Globalizzazione Neoliberista. Rassegna italiana di sociologia XLVI(2):249-274.

Anheier, Helmut, Marlies Glasius, and Mary Kaldor, eds. (2001) Global Civil Society Yearbook 2001. Oxford: Oxford University Press.

Arbour, Louise. (2008) The Responsibility to Protect as a Duty of Care in International Law and Practice. Review of International Studies 34(3):445-458.

Archibugi, Daniele. (2004) Cosmopolitan Guidelines for Humanitarian Intervention. Alternatives $29(1): 1-21$.

Archibugi, Daniele. (2008) A Commonwealth of Citizens. Cosmopolitical Perspectives. Princeton, NJ: Princeton University Press.

Archibugi, Daniele, David Held, and Martin Köhler, eds. (1998) Re-Imagining Political Community: Studies in Cosmopolitan Democracy. Cambridge: Polity Press.

Archibugi, Daniele, Sveva Balduini, and Marco Donati. (2000) The United Nations as an Agency of Global Democracy. In Global Democracy, edited by B. Holden, ED. London: Routledge.

Armstrong, David, Theo Farrell, and Bice Maiguashca, eds. (2003) Governance and Resistance in World Politics. Cambridge: Cambridge University Press.

Arrighi, Giovanni. (1999) The Global Market. Journal of World-Systems Research V 2:217-251.

Arts, Bas, Math Noortmann, and Bob Reinalda, eds. (2001) Non-State Actors in International Relations. Aldershot: Ashgate.

Asher, Chris. (1950) The Development of UNESCO Programme. International Organization 4(1):12-26.

Barnet, Richard, and John Cavanagh. (1994) Global Dreams: Imperial Corporations and the New World Order. New York: Simon and Shuster.

Barnet, Richard, and Ronald E. Müller. (1974) Global Reach: The Power of the Multinational Corporations. New York: Simon and Shuster.

Barry, Brian. ([1991] 2005) Humanity and Justice in Global Perspective. In Contemporary Political Philosophy, edited by G. Robert and R. Philip, London: Blackwell.

Bastiat, Frederic. ([1845] 1964) Economic Sophisms. Princeton, NJ: Van Nostrand.

Beck, Ulrich, and Edgar Grande. (2004, Trans. 2007) Cosmopolitan Europe. Cambridge: Polity.

Becker, Gary S. (1976) The Economic Approach to Human Behavior. Chicago, IL: University of Chicago Press.

Bellamy, Richard, and Dario Castiglione. (1998) Between Cosmopolis and Community: Three Models of Rights and Democracy Within the European Union. In Re-Imagining Political Community: Studies in Cosmopolitan Democracy, edited by D. Archibugi, D. Held, and M. Koehler, EDS. Cambridge: Polity.

Bello, Walden. (2002) Deglobalization: Ideas for a New World Economy. London: Zed.

Benford, Robert D., and David A. Snow. (2000) Framing Processes and Social Movements: An Overview and Assessment. Annual Review of Sociology (26):611-639.

Bhagwati, Jagdish. (1997) Globalization, Sovereignty, and Democracy. In Democracy's Victory and Crisis. edited by Axel Hadenius, ED. Cambridge: Cambridge University Press.

Bhagwati, Jagdish. (2004) In Defence of Globalization. Oxford: Oxford University Press.

Bienen, Derk, Volker Rittberger, and Wolfang Wagner. (1998) Democracy in the United Nations System: Cosmopolitan and Communitarian Principles. In Re-Imagining Political Community: Studies in Cosmopolitan Democracy. edited by D. Archibugi, D. Held, and M. Köhler, Cambridge: Polity Press.

Bond, Patrick. (2004) Talk Left, Walk Right: South Africa's Frustrated Global Reforms. Scottsville: University of KwaZulu-Natal Press.

Bond, Patrick. (2007) Reformist Reforms, Non-Reformist Reforms and Global Justice: Activist, NGO and Intellectual Challenges in the World Social Forum. Societies Without Borders 3:4-19.

Brecher, Jeremy, Tim Costello, and Brendan Smith. (2000) Globalization From Below. The Power of Solidarity. Cambridge: South End Press. 
Brittan, Samuel. (1988) A Restatement of Economic Liberalism, 2nd edition. Basingstoke: Macmillan.

Buchanan, James M. (1976) The Justice of Natural Liberty. Journal of Legal Studies 5:1-16.

Buchanan, Ruth. (2003) Perpetual Peace or Perpetual Process: Global Civil Society and Cosmopolitan Legality at the World Trade Organization. Leiden Journal of International Law 16:673-699.

Cabrera, Luis. (2005) The Cosmopolitan Imperative: Global Justice Through Accountable Integration. The Journal of Ethics 9:171-199.

Cakmak, Cenap. (2008) Transnational Activism in World Politics and Effectiveness of a Loosely Organised Principled Global Network: The Case of the NGO Coalition for an International Criminal Court. The International Journal of Human Rights 12(3):373-393.

Camilleri, Joseph A. (2004) Rights and Pluralism in a Globalising World: The Role of Civilizational Dialogue. Paper presented at the "Islamic-Western Dialogue on Governance Values. Rights and Religious Pluralism" Workshop, Canberra.

Camilleri, Joseph A., Malhorta Kamal, and Tehranian Majid. (2000) Reimagining the Future: Towards Democratic Governance. Bundoora, Victoria: La Trobe University.

Caney, Simon. (2004) Justice Beyond Borders. A Global Political Theory. Oxford: Oxford University Press.

Carroll, William K, and Colin Carson. (2003) Forging a New Hegemony? The Role of Transnational Policy Groups in the Network and Discourses of Global Corporate Governance Journal of World-Systems Research IX 1:67-102.

Cassano, Franco, and Danilo Zolo, eds. (2007) L'alternativa Mediterranea. Milano: Feltrinelli.

Charnovitz, Steve. (2004) The WTO and Cosmopolitics. Journal of International Economic Law $7(3): 675-682$.

Chen, M. A.. (1995) Engendering World Conferences: The International Women's Movement and the United Nations. Third World Quarterly 16:477-493.

Clark, IAn. (2007) International Legitimacy and World Society. Oxford: Oxford University Press.

Commission on Global Governance. (1995) Our Global Neighbourhood. Oxford: Oxford University Press.

Conca, Ken. (1995) Greening the United Nations: Environmental Organisations and the UN System. Third World Quarterly 16(3):441-447.

Cronin, Bruce. (2002) The Two Faces of the United Nations: The Tension Between Intergovernmentalism and Transnationalism. Global Governance 8(1):53-71.

Czempiel, Ernst Otto, and James N. Rosenau. (1992) Governance Without Government: Order and Change in World Politics. Cambridge: Cambridge University Press.

Dallmayr, Fred. (1996) Beyond Orientalism: Essays on Cross-Cultural Encounter. New York: State University of New York Press.

Dallmayr, Fred. (2001) Dialogue of Civilizations: A Gadamerian Perspective. Global Dialogue 3:67-75.

Dallmayr, Fred. (2003) Dialogue Among Civilizations: Some Exemplary Voices. London: Palgrave.

Day, Allan. (2002) The Prospects of a Cosmopolitan World Order: Investigating the 2002 United Nations Finance for Development Conference. Global Social Policy 2(3):295-318.

De Sousa Santos, Boaventura. (2002) Toward a New Legal Common Sense: Law, Globalization and Emancipation. London: Butterworths LexisNexis.

de Sousa Santos, Boaventura. (2005) Beyond Neoliberal Governance: The World Social Forum as Subaltern Cosmopolitan Politics and Legality. In Law and Globalization From Below: Toward a Cosmopolitan Legality, edited by B.. de Sousa Santos and C. Rodríguez-Garavito. Cambridge: Cambridge University Press.

de Sousa Santos, Boaventura. (2006) The Rise of the Global Left: The World Social Forum and Beyond. London: Zed Books.

de Sousa Santos, Boaventura, and César A. Rodríguez-Garavito, eds. (2005) Law and Globalization From Below: Toward a Cosmopolitan Legality. Cambridge: Cambridge University Press.

Delanty, Gerard. (2005) The Idea of a Cosmopolitan Europe. International Review of Sociology $15(3): 405-421$.

della Porta, Donatella. (2005) Making the Polis: Social Forum and Democracy in the Global Justice Movement. Mobilization 10(1):73-94.

della Porta, Donatella, and Sidney Tarrow, eds. (2005) Transnational Protest and Global Activism. Lanham, MD: Rowan and Littlefield.

Dirlik, A., AND R. Prazniak, Eds. (2001) Places and Politics in an Age of Globalization. Lanham, MD: Rowan and Littlefield.

Duchêne, Francois. (1972) Europe's Role in World Peace. In Europe Tomorrow, edited by R. Mayne London: Fontana.

Eleftheriadis, Pavlos. (2001) The European Constitution and Cosmopolitan Ideals. Columbia Journal of European Law 7(1):21-39. 
Eleftheriadis, Pavlos. (2003) Cosmopolitan Law. European Law Journal 9(2):241-263.

Eriksen, Erik Oddvar. (2006) The EU-A Cosmopolitan Polity? Journal of European Public Policy $13(2): 252-269$.

Eriksen, Erik Oddvar, and John Erik Fossum. (2005) The Prospect for a Post-National Citizens' Europe. Florence, SC: Cidel-wp18.

European Commission. (2004) Dialogue Between Peoples and Cultures in the Euro-Mediterranean Area. Report by the High-Level Advisory Group established at the Initiative of the President of the European Commission. Brussels: European Commission.

FAlk, Richard. (1995) On Humane Governance: Toward a New Global Politics. Cambridge: Polity.

Falk, Richard. (2005) Reforming the United Nations: Global Civil Society Perspectives and Initiatives. In Global Civil Society 2005/2006, edited by M.. Glasius, M. Kaldor, and H. Anheier. London: Sage.

Faulkner, Frank, ED. (2007) Moral Entrepreneurs and the Campaign to Ban Landmines, New York: Rodopi Press.

Finnemore, Martha, and Kathryn Sikkink. (1998) International Norms Dynamics and Political Change. International Organization 52(4):887-917.

Fisher, Kim. (1997) Locating Frames in the Discursive Universe. Sociological Research Online 2(3). http://socresonline.org.uk/socresonline/2/3/4.html.

Foreign Affairs, ED. (1996) Samuel P. Huntington's The Clash of Civilizations? The Debate. New York: Foreign Affairs/WW Norton.

Fougner, Tore. (2005) "Making States Compete. The 'Invisible Hand' of the World Economic Forum in Global Economic Governance". Paper presented at the First Global International Studies Conference, Instanbul.

Fung, Archon, and Erik Olin Wright. (2003) Deepening Democracy: Institutional Innovations in Empowered Participative Governance. London: Verso.

Gerring, John. (1997) Ideology: A Definitional Analysis. Political Research Quarterly 50(4):957-994.

Gibson-Graham, J. K. (2006) A Postcapitalist Politics. Minneapolis, MN: University of Minnesota Press.

Gill, Stephen. (1990) American Hegemony and the Trilateral Commission. Cambridge: Cambridge University Press.

Gills, BARry K., ED. (2000) Globalization and the Politics of Resistance. Basingstoke: Macmillan.

Glasius, Marlies. (2005) The International Criminal Court: A Global Civil Society Achievement. London: Routledge.

Goffman, Ervin. (1974) Frame Analysis: An Essay on the Organisation of the Experience. New York: Harper Colophon.

Goodman, Nelson. (1978) Ways of Worldmaking. Indianapolis: Hackett.

Gould, Carol. (2004) Globalizing Democracy and Human Rights. Cambridge: Cambridge University Press.

Graz, Jean-Christophe. (2003) How Powerful are Transnational Elites Clubs? The Social Myth of the World Economic Forum New Political Economy 8(3):321-340.

Harvey, David. (2007) A Brief History of Neoliberalism. Oxford: Oxford University Press.

Hassner, Pierre. (1998) Refugees: A Special Case for Cosmopolitan Citizenship? In Re-Imagining Political Community. Studies in Cosmopolitan Democracy, edited by D. Archibugi, H. David, and M. Koehler. Cambridge: Polity

Haufler, Virginia. (2001) A Public Role for the Private Sector: Industry Self-Regulation in a Global Economy. Washington, DC: Carnegie Endowment for International Peace.

Hayden, Patrick (2005). Cosmopolitan Global Politics. Aldershot: Ashgate.

Heater, Derek. (1996) World Citizenship and Government: Cosmopolitan Ideas in the History of Western Political Thought. Basingstoke: Macmillan.

Held, David. (1995) Democracy and the Global Order: From the Modern State to Cosmopolitan Governance. Cambridge: Polity.

Held, David, And Anthony McGrew, eds. (2000) The Global Transformations Reader: An Introduction to the Globalization Debate. Cambridge: Polity.

Held, David, And Anthony McGrew. (2002a) Globalization/Anti-Globalization. Cambridge: Polity.

Held, David, and Anthony McGrew, eds. (2002b) Governing Globalization: Power, Authority and Global Governance. Cambridge: Polity.

Held, David, Anthony McGrew, D. Goldblatt, and J. Perraton. (1999) Global Transformations: Politics, Economics and Culture. Cambridge: Polity.

Higgott, Richard A., Geoffrey R. D. Underhill, and Andreas Bieler, eds. (2000) Non-State Actors and Authority in the Global System. New York: Routledge.

Hines, Colin. (2000) Localization: A Global Manifesto. London: Earthscan. 
Holloway, John. (2000) Change the World Without Taking Power: The Meaning of Revolution Today. London: Pluto.

Huntington, Samuel P. (1993) Clash of Civilizations? Foreign Affairs 72(3):22-49.

Huntington, Samuel P. (1996) The Clash of Civilizations and the Remaking of World Order. New York: Simon and Shuster.

ICISS. (2001) Report of the International Commission on Intervention and State Sovereignty. Ottawa: The International Development Research Centre.

ISESCO. (2001) White Book on Dialogue Among Civilizations. Rabat: Islamic Educational, Scientific and Cultural Organization-ISESCO.

ISESCO. (2004) Islamic Declaration on Cultural Diversity (Adopted by the 4th Islamic Conference of Culture Ministers). Algiers: Islamic Educational, Scientific and Cultural Organization (ISESCO).

Jintao, Hu. (2006) Speech delivered at Yale University, New Haven, CT.

Jintao, Hu. (2008) Speech delivered at Opening Ceremony of the Boao Forum for Asia Annual Conference, Boao, Hainan.

Kacowicz, Arie M. (2005) The Normative Dimension of Alternative 21st Century World Orders. Paper presented at the WISC/ISA Conference, Istanbul.

Karagiannis, Nathalie, and Peter Wagner, Eds. (2007) Varieties of World-Making: Beyond Globalization. Liverpool: Liverpool University Press.

Keohane, Robert. (1984) After Hegemony: Cooperation and Discord in the World Political Economy. Princeton, NJ: Princeton University Press.

Keohane, Robert, and Joseph Nye. (1972) Transnational Relations and World Politics. Cambridge, MA: Harvard University Press.

Кнатамi, Монамmad. (1998) Islam, Liberty, and Development. Binghamton, NY: Binghamton University.

Khatami, Mohammad. (2000) Islam, Dialogue, and Civil Society. Canberra: The Centre for Arabic and Islamic Studies, the Middle East and Central Asia-ANU.

Khatami, Mohammad. (2001) Dialogue Among Civilizations [In Persian]. Teheran: Tarh-e-No Publication.

Khatami, Mohammad. (2006) Message to the Third Meeting of the High-Level Group for the Alliance of Civilizations, Tehran.

KIM, Yersu. (1999) A Common Framework for the Ethics of the 21st Century. (A Report by the Director of the UNESCO Division of Philosophy and Ethics). Paris: UNESCO-DRG-99/WS/3.

Koenig-Archibugi, Mathias. (2002) Mapping Global Governance. In Governing Globalization, edited by D. Held and A. McGrew, Cambridge: Polity Press.

Korten, David. (1995) When Corporations Rule the World. West Hartford, CT: Berrett-Koehler.

Küng, Hans, and Karl-Josef Kuschel, eds. (1995) A Global Ethic: The Declaration of the Parliament of the World's Religions. London: Continuum.

Kuper, Andrew. (2004) Democracy Beyond Borders. Oxford: Oxford University Press.

Laclau, Ernesto. (1996) The Death and Resurrection of the Theory of Ideology. Journal of Political Ideologies 1(3):201-220.

Lamy, Pascal. (2001) Harnessing Globalization: Do We Need Cosmopolitics? Speech at LSE, London, 1 February.

Lang, T., And C. Hines. (1993) The New Protectionism: Protecting the Future Against Free Trade. New York: New Press.

Laraña, Enrique, Hank Johnston, and Joseph Gusfield, eds. (1994) New Social Movements: From Ideology to Identity. Philadelphia, PA: Temple University Press.

Manners, IAn. (2002) Normative Power Europe: A Contradiction in Terms? Journal of Common Market Studies 40(2):235-258.

Manners, Ian. (2006) Normative Power Europe Reconsidered: Beyond the Crossroads. Journal of European Public Policy 13(2):182-199.

Manonelles, Manuel. (2007) Building an Alliance of Civilizations. Pace diritti umani IV(1):41-50.

Manoochehri, Abbas. (2003) Enrique Dussel and Ali Shari'ati on Cultural Imperialism. Intercultural Studies 1(Spring). http:/ / www.intercultural-studies.org/ICS1/Manoocheri.html.

Marchetti, Raffaele. (2005) Interaction-Dependent Justice and the Problem of International Exclusion. Constellations 12(4):487-501.

Marchetti, Raffaele. (2006) Human Rights as Global Participatory Entitlements. In Between Cosmopolitan Ideals and State Sovereignty. Studies on Global Justice, edited by R. Tinnevelt and G. Verschraegen. London: Palgrave-Macmillan.

Marchetti, Raffaele. (2008a) Global Democracy: For and Against. Ethical Theory, Institutional Design, and Social Struggles. London-New York: Routledge. 
Marchetti, Raffaele. (2008b) A Matter of Drawing Boundaries: Global Democracy and International Exclusion. Review of International Studies 34(2):207-224.

McAdam, Doug, John D. McCarthy, and Mayer N. Zald. (1996) Comparative Perspectives on Social Movements: Political Opportunities, Mobilizing Structures, and Cultural Framings. Cambridge: Cambridge University Press.

Monbiot, George. (2005) Manifesto for a New World Order. New York: The New Press.

Morton, Adam David. (2002) "La Resurreccion del Maiz": Globalisation, Resistance and the Zapatistas. Millennium. Journal of International Studies 31(1):27-54.

Mundy, Simon. (2006) Thinking Beyond Nations: A New Approach to World Regions. Paper presented at the World Public Forum-Dialogue Among Civilizations, Rodhos.

Nancy, Jean-Luc. (2002) La Création du Monde ou la Mondialisation. Paris: Galilée.

Norberg, Johan, Roger Tanner, And Julian Sanchez. (2003) In Defence of Global Capitalism. Washington, DC: Cato Institute.

Norris, Pippa. (2008) Confidence in the United Nations: Cosmopolitan and Nationalistic Attitudes. In The Global System: Democracy and Values, edited by Y. Esmer and T. Pettersson. Uppsala: Uppsala University Press.

Nozick, Robert. (1974) Anarchy, State and Utopia. New York, NY: Basic Books.

O'Brien, Robert, Anne Marie Goetz, Jan Aart Scholte, and Marc Williams. (2000) Contesting Global Governance: Multilateral Economic Institutions and Global Social Movements. Cambridge: Cambridge University Press.

Ohmae, Kenichi. (1999) The Borderless World: Power and Strategy in the Interlinked Economy. New York: Harper Business.

Olesen, Thomas. (2005) International Zapatismo. The Construction of Solidarity in the Age of Globalization. London: Zed Books.

Oliver, Pamela, and Hank Johnston. (2000) What A Good Idea! Ideology and Frames in Social Movement Research. Mobilization 5(1):37-54.

Osterweil, Michal. (2005) Place-Based Globalism: Theorizing the Global Justice Movement. Development $48(2): 23-28$.

Patomäki, Heikki, and Teivo Teivainen. (2004) A Possible World. Democratic Transformation of Global Institutions. London: Zed.

Pavone, Vincenzo. (2007) From Intergovernmental to Global: UNESCO's Response to Globalization. Review of International Organization 2(1):77-95.

Petersmann, E. Ulrich. (2001a) European and International Constitutional law : Time for Promoting "Cosmopolitan Democracy" in the WTO. In The EU and the WTO: Legal and Constitutional Issues, edited by G. de Búrka and J. Scott. Oxford: Hart Publishing.

Petersmann, E. Ulrich. (2001b) Human Rights, Cosmopolitan Democracy and the Law of the World Trade Organisation. In Foundations and Perspectives of International Trade Law, edited by I. Fletcher, L. Mistelis, and M. Cremona. London: Sweet \& Maxwell.

Petito, F. (2007) The Global Political Discourse of the Dialogue among Civilizations: Mohammad Khatami and Vaclav Havel. Global Change, Peace E Security 19(2):103-126.

Pettifor, A. (1998) The Economic Bondage of Debt and the Birth of a New Movement. New Left Review 230:115-122.

Pianta, Mario, and Raffaele Marchetti. (2007) The Global Justice Movements: The Transnational Dimension. In The Global Justice Movement: A Cross-National and Transnational Perspective, edited by D. della Porta. Boulder, CO: Paradigm.

Pianta, Mario, and Federico Silva. (2003) Globalisers From Below. A Survey on Global Civil Society Organisations, Roma: Globi Research Report.

Pianta, Mario, and Duccio Zola. (2007) La Montée en Puissance des Mouvements Globaux 19702005. In La Généalogie des Mouvements Altermondialistes, edited by I. Sommier, O. Fillieule, and E. Agrikolinasky, EDs. Paris: Karthala.

Picco, Giandomenico, Ed. (2001) Crossing the Divide. Dialogue Among Civilizations. South Orange, NJ: Seton Hall University.

Pogge, Thomas. (1992) Cosmopolitanism and Sovereignty. Ethics 103(1):48-75.

Pogge, Thomas. (1997) Creating Supra-National Institutions Democratically: Reflections on the European Union's 'Democratic Deficit.' Journal of Political Philosophy 5(2):163-182.

Pogge, Thomas. (2002) World Poverty and Human Rights: Cosmopolitan Responsibilities and Reforms. Cambridge: Polity.

Pogge, Thomas. (2004) Kant's Vision, Europe, and a Global Federation. In Kant's Perpetual Peace. New Interpretative Essays, edited by L. Caranti. Rome: Luiss University Press. 
Polletta, Francesca. (2002) Freedom Is an Endless Meeting: Democracy in American Social Movements. Chicago, IL: Chicago University Press.

Porter, Michael E., Klaus Schwab, and Augusto Lopez-Claros. (2005) The Global Competitiveness Report 2005-2006. Basingstoke: World Economic Forum-Palgrave Macmillan.

Price, Richard. (2003) Transnational Civil Society and Advocacy. World Politics 55(4):579-607.

Putin, Vladimir. (2005) Speech delivered at the High-Level Plenary Meeting of the 60th UN General Assembly, New York.

Putin, Vladimir. (2007) Speech delivered at the 43rd Munich Conference on Security Policy, Munich.

Rajagopal, Balakrishnan. (2003) International Law From Below. Development, Social Movements and Third World Resistance. Cambridge: Cambridge University Press.

Rand, Ayn. (1961) The Virtue of Selfishness. New York: Signet-Penguin.

Riknila, Leena, and Katarina Sehm-Patomäki, Eds. (2001) Democracy and Globalization: Promoting a North-South Dialogue. Helsinki: Network Institute for Global Democratization.

Rosenau, James N. (1992) Citizenship in a Changing Global Order. In Governance Without Government: Order and Change in World Politics, edited by J.N. Rosenau and E.O. Czempiel, EDs. Cambridge: Cambridge University Press.

Rosenau, James N. (1997) Along the Domestic-Foreign Frontier: Exploring Governance in a Turbulent World. Cambridge: Cambridge University Press.

Rothbard, Murray. (1982) Ethics of Liberty. Atlantic Highlands: Humanities Press.

Ruggie, John G. (1983) International Regimes, Transactions, and Change: Embedded Liberalism in the Postwar Economic Order. In International Regimes, edited by S.D. Krasner. Ithaca, NY: Cornell University Press.

Ruggie, John G. (1995) At Home Abroad, Abroad at Home: International Liberalization and Domestic Stability in the New World Economy. Millennium. Journal of International Studies 24(3):507526.

Ruggie, John G. (2004) Reconstituting the Global Public Domain-Issues, Actors, and Practices. European Journal of International Relations 10(4):499-531.

Sally, Razeen. (2001) Hayek and International Economic Order. Ama-Gi 4(1):7-13.

Sassen, Saskia. (1996) Losing Control? Sovereignty in an Age of Globalization. New York: Columbia University Press.

Scholte, Jan Aart. (2004) Democratizing the Global Economy. The Role of Civil Society. Warwick: Centre for the Study of Globalisation and Regionalisation, University of Warwick.

Schulz, Markus S. (1998) Collective Action Across Borders: Opportunity Structures, Network Capacities, and Communicative Praxis in the Age of Advanced Globalization. Sociological Perspectives $41(3): 587-616$.

Schwab, Klaus, Michael E. Porter, Jeffrey D. Sachs, Andrew M. Warner, and Macha Levinson (1999) The Global Competitiveness Report 1999. Geneva: World Economic Forum.

Seckinelgin, Hakan. (2007) International Politics of HIV/AIDS: Global Disease-Local Pain. London: Routledge.

Sen, Jay, A. Anand, A. Escobar, and P. Waterman, eds. (2004) World Social Forum. Challenging Empires. New Delhi: The Viveka Foundation.

Seonne, Josè, and Emilio Taddei, eds. (2001) Resistencias Mundiales. De Seattle a Porto Alegre. Buenos Aires: Clacso.

Singer, Peter. (1972) Famine, Affluence, and Morality. Philosophy and Public Affairs 1(3):229-243.

Sjursen, Helene. (2006) The EU as a 'Normative Power': How Can This Be? Journal of European Public Policy 13(2):235-251.

Sklair, Lesli. (1999) Competing Conceptions of Globalization. Journal of World-Systems Research $\mathrm{V}(2): 143-163$.

Slaughter, Anne-Marie. (2004) A New World Order. Princeton, NJ: Princeton University Press.

Smith, Jackie. (2002) Bridging Global Divide? Strategic Framing and Solidarity in Transnational Social Movement Organizations International Sociology 17(4):505-528.

Smith, Jackie. (2004) The World Social Forum and the Challenges of Democracy. Global Networks $4(4): 413-421$.

Smith, Jackie. (2007) Social Movements for Global Democracy. Baltimore: John Hopkins University Press.

Smith, Jackie, And Hank Johnston, Eds. (2002) Globalization and Resistance: Transnational Dimensions of Social Movements. Lanham, MD: Rowan and Littlefield.

Smith, Jackie, C. Chatfield, and R. Pagnucco, eds. (1997) Transnational Social Movements and Global Politics. Solidarity Beyond the State. Syracuse, NY: Syracuse University Press. 
Smith, Jackie, R. Pagnucco, and G. A. Lopez. (1998) Globalizing Human Rights: The Work of Transnational Human Rights NGOs in the 1990s. Human Rights Quarterly 20:379-412.

Snow, David A., And Robert D. Benford. (2000) Clarifying the Relationship Between Framing and Ideology. Mobilization 5(1):55-60.

Starr, Amory, and Jason Adams. (2003) Anti-Globalization: The Global Fight for Local Autonomy. New Political Science 25(1):19-42.

Steger, Manfred B. (2008) The Rise of the Global Imaginary. Political Ideologies from the French Revolution to the Global War on Terror. Oxford: Oxford University Press.

Stiglitz, Joseph E. (2002) Globalization and Its Discontents. Harmondsworth: Penguin.

Tarrow, Sidney. (1998) Power in Movement. Social Movements and Contentious Politics. Cambridge: Cambridge University Press.

Tarrow, Sidney. (2005) The New Transnational Activism. Cambridge: Cambridge University Press.

TAYlor, P. (1999) The United Nations in the 1990s: Proactive Cosmopolitanism and the Issue of Sovereignty. Political Studies 47:538-565.

Tehranian, Majid, and David W Chappell, eds. (2002) Dialogue of Civilizations: A New Peace Agenda for a New Millennium. London: I. B. Tauris.

Teivainen, Teivo. (2002) The World Social Forum and Global Democratisation: Learning From Porto Alegre. Third World Quarterly 23(4):621-632.

Thibault, Jean-Francoise. (2003) “The Political Philosophy of Global Governance." Paper presented International Symposium International Norms for the 21st Century, Aix en Provence.

Tyler, Patrick. (2003) A New Power In the Streets. New York Times, February 17.

UNDP, EDS. (1999) Human Development Report 1999_Globalization. Oxford: Oxford University Press.

UNESCO. (1994) The Culture of Peace Programme: From National Programmes to a Project of Global Scope. Paris: UNESCO-145 EX/15, August.

UNESCO. (1998) The Universal Ethics Project (Preliminary Report and Archive of Participant Contributions). Paris: UNESCO-Division of Philosophy and Ethics.

United Nations. (2001a) Global Agenda for Dialogue Among Civilizations. New York: UN General Assembly (A/RES/56/6).

United Nations. (2001b) Report of the Secretary-General on the United Nations Year of Dialogue Among Civilizations. New York: UN (A/56/523).

United Nations. (2004) A More Secure World: Our Shared Responsibility. New York: Report of the Secretary-General's High-level Panel on Threats, Challenges and Change. Commission Panyarachun.

United Nations. (2005) In Larger Freedom. Toward Development, Security and Human Rights for All (No. A/59/2005). New York: UN.

United Nations. (2006) Alliance of Civilizations. Report of the High-Level Group: UN (November 13).

VAn den Anker, Christien. (2006) Institutional Implications of Global Justice as Impartiality: Cosmopolitan Democracy. Global Society 20(3):267-286.

VAN Der Pijl, KeEs. (1998) Transnational Classes and International Relations. London: Routledge.

Van Rooy, Alison. (1997) The Frontiers of Influence: NGO Lobbying at the 1974 World Food Conference, the 1992 Earth Summit and Beyond. World Development 25(1):93-114.

Vercelli, Alessandro. (2003) Updated Liberalism vs. Neo-Liberalism: Policy Paradigms and the Structural Evolution of Western Industrial Economies After W.W. II, Vercelli: Quaderni del dipartimento di economia politica (398).

Wagner, Peter. (2006) Social Theory and Political Philosophy. In Social Theory and Political Philosophy, edited by G. Delanty. London: Routledge.

Wendt, Alexander. (1995) Constructing International Politics. International Security 20(1):71-81.

Wolf, Martin. (2004) Why Globalization Works. New Haven, CT: Yale University Press.

Wood, David. (2000) The International Campaign Against the Multilateral Agreement on Investment: A Test Case for the Future of Globalisation? Ethics, Place and Environment 3(1):25-45.

Woods, Ngaire. (2000) The Political Economy of Globalization. London: Macmillan.

World Public Forum. (2004) Rodhos Declaration 2004, Rodhos: World Public Forum-Dialogue of Civilizations.

Zürn, Michael. (2004) Global Governance and Legitimacy Problems. Government and Opposition 39(2):260-287. 